\title{
NANOKOMPOSIT KARET ALAM/SILIKON SEBAGAI OTOT SINTETIK DENGAN SIFAT MEKANIK SEPERTI OTOT MANUSIA
}

\author{
Riri Murniati* \\ Departemen Ilmu Komputer, Fakultas Matematika dan Ilmu Pengetahuan Alam, \\ Universitas Pakuan, Jalan Pakuan PO.BOX 452, Telp/Fax. (0251) 8375547 \\ Bogor, Indonesia \\ *Korespondensi ke: ririmurniati@ymail.com
}

( Diterima:01 Februari 2018; Direvisi: 21 Februari 2018; Diterbitkan: 01 Maret 2018)

\begin{abstract}
ABSTRAK
Penggunaan kadaver di dalam studi medis sudah lazim digunakan terutama sebagai media pembelajaran dan pelatihan tindakan medis seperti bedah. Akan tetapi kadaver manusia membawa sejumlah masalah yang tidak dapat dihindari. Sehingga perlu dicari material substitusi yang dapat digunakan untuk mengganti kadaver. Penggunaan material substitusi ini perlu memperhatikan potensi Indonesia agar dapat membantu perkembangan bangsa. Indonesia sendiri merupakan negara penghasil karet alam terbesar kedua di dunia. Maka dipilihlah komposit karet alam sebagai pengganti kadaver manusia. Penelitian ini dilakukan untuk melihat karakteristik dari komposit karet alam yang disintesis tersebut. Selain itu komposisi material yang digunakan juga penting untuk diperhatikan. Material yang digunakan adalah foaming agent, gelling agent, curing agent, activator, stabilizer dan filler. Filler yang akan digunakan adalah nanosilika, kaolin dan kalsium karbonat. Material yang telah dibakar kemudian dikarakterisasi mekanik dengan Universal Testing Machine untuk menentukan modulus Young dan FTIR untuk melihat struktur gugus fungsi penyusun nanokomposit dari polimer karet alam ini. Pengujian sampel kontrol juga dilakukan pada sampel yang dibuat dari karet sintetis (silikon) dan daging sapi. Penelitian ini menghasilkan beberapa material yang memiliki kemiripan karakteristik mekanik dengan anggota tubuh bagian dalam. Karet komposit lateks 50\% dan Silikon 50\% pengujian 1 (0,070 $\mathrm{MPa})$ menyerupai kerongkongan $(0,77 \mathrm{MPa})$ serta pengujian $2(0,041 \mathrm{MPa})$ memiliki karakteristik mekanik yang menyerupai usus manusia (0,0356 MPa). Karet komposit lateks $75 \%$ dan Silikon $25 \%$ pengujian 1 $(0,196 \mathrm{MPa})$ dan pengujian $2(0.136 \mathrm{MPa})$, memiliki karakteristik menyerupai tulang rawan pada lutut pria remaja $(0,13 \mathrm{MPa})$.

Kata kunci:Kadaver, karet alam, karakteristik mekanik, silikon
\end{abstract}




\begin{abstract}
Utilization of human cadaver in medical study has been commonly use especially as a tool in medical practice. Nonetheless, human cadaver brought inevitable problems. Thus, a substitute material is necessary to diminish the usage of human cadaver. Utilization of this subtitute materials have to consider potential of Indonesia as second largest natural rubber producen in the world. So natural rubber composite has been chosen as subtitute material to replace cadaver. The purpose of this research is to synthesize and characterize natural rubber nanocomposite that has a mechanical characteristic similar to the mechanical characteristic of human tissue. Natural rubber in form of latex was initially processed using foaming agent, gelling agent, curing agent, activator, and stabilizer. Then, filler variance of nanosilica, CaCO3 and caolin was added. The produced materials were then characterized by using Universal Testing Machine to determine Young's modulus and then tested with the incision test equipment specially designed by our own team. Mechanical characteristics of different human body part tissue were compared to the control samples were made from synthetic rubber (silicone) and beef. This study resulted samples that have similar mechanical characteristics with limbs inside.

Keywords:Cadever, natural rubber, mechanical characteristics, silicon
\end{abstract}

\title{
1. PENDAHULUAN
}

Dalam dunia kedokteran, cadaver (tubuh manusia yang sudah dibekukan) seringkali digunakan sebagai objek pembelajaran dan penelitian. Akan tetapi timbul masalah dibalik penggunaan cadaver tersebut. Permasalahan yang pertama adalah masalah moralitas. Secara moral, masyarakat masih belum bisa menerima kenyataan bahwa ada tubuh manusia yang dibedah untuk menjadi objek penelitian. Walaupun sudah berwujud cadaver, namun tubuh tersebut tetaplah manusia. Perlakuan yang diberikan pada cadaver tersebut haruslah diperhatikan. Masalah berikutnya yang muncul adalah batas waktu penggunaan cadaver. Karena merupakan bahan organik yang berasal dari tubuh manusia, setelah jangka waktu tertentu cadaver akan mengalami pembusukan walaupun sudah diberikan pengawet jenazah. Sehingga cadaver pun pada akhirnya harus dimakamkan juga. Fakultas Kedokteran biasanya memperoleh cadaver dengan mencari jenazahjenazah tak beridentitas dari rumah sakit. Hanya jenazah yang tidak memiliki identitas saja dan tidak ada anggota keluarganya yang mengambil jenazah tersebut yang boleh diambil sebagai cadaver. Maka cadaver yang nantinya dipelajari oleh mahasiswa kedokteran berasal dari rentang umur dan kondisi yang benar-benar acak. Disisi lain, harga yang harus ditebus untuk kadaver manusia pun tidaklah murah. Sehingga pembelajaran yang diperoleh mahasiswa kedokteran pun menemui banyak sekali keterbatasan.

Pada tahun 2008, F.Ayers dan timnya meneliti tentang fabrikasi dan karakterisasi jaringan phantom berbasis silikon dengan sifat optik dalam domain inframerah tampak dan dekat. Jaringan simulasi phantom optik memainkan peran sentral dalam pengembangan, validasi, dan penerapan teknologi biomedis berbasis optik (F. Ayers, dkk, 2008). Penggunaan jaringan simulasi phantom optik merupakan bagian penting dari pengembangan lanjutan dan adopsi dari teknik-teknik klinis berbasis optik. Sementara phantom cair mungkin yang paling mudah diproduksi dan dikarakterisasi, ada sejumlah aplikasi phantom yang padat sebagai opsi permanen yang akan lebih cocok. Sebuah jaringan simulasi phantom terbuat dari bahan bulk dimana agen hamburan dan agen 
penyerap juga ditambahkan. Sampai saat ini, berbagai bahan dan agen optik telah digunakan untuk memproduksi phantom (Pogue dan Patterson, 2006).

Di Indonesia, karet alam merupakan sumber devisa terbesar ketiga setelah migas dan kayu. Lebih dari 10 juta pekebun karet yang penghasilannya bergantung pada bidang ini. Pendapatan devisa dari komoditi ini pada tahun 2005 mencapai US\$ 2,58 milyar (Kemenristek RI, 2014). Sehingga perlu adanya upaya hilirisasi, upaya tersebut terutama untuk SIR 20 dengan produksi sekitar lebih dari $85 \%$ dari total produksi karet alam Indonesia. Karenanya jika menggunakan bahan baku SIR 20 harus dipilih produkproduk yang memerlukan elatisitas yang baik seperti bantalan dermaga dan sifat menahan beban yang lain seperti bantalan gempa, juga bisa produk lain yang bisa untuk mensubtitusi bahan lain seperti penutup air yang biasanya memakai kayu. Namun upaya hilirisasi tersebut sangatlah terbatas, maka kami memikirkan alternatif hilirisasi lain yang bisa menyerap bahan baku karet alam sebanyak mungkin dengan kebermanfaatan yang bisa jadi solusi terhadap permasalahan lokal yang terjadi di Indonesia. Salah satunya di dunia medis, sehingga diharapkan kedua permasalahan di atas bisa terjawab sekaligus melalui penelitian ini.

\section{METODE PENELITIAN}

Peralatan yang dibutuhkan antara lain cetakan besi yang terbuat dari stainless steel (dimensi), neraca digital, oven (Suhu dari $0^{\circ} \mathrm{C}-250^{\circ} \mathrm{C}$ ), gelas beaker $50 \mathrm{~mL}$ dan $250 \mathrm{~mL}$, baskom $1000 \mathrm{~mL}$, mixer tangan (5 konfigurasi kecepatan), forceps, ultrasonic bath, thermometer, hot presser, SEM EDS, UTM, FTIR. Sedangkan bahan utama yang dipakai adalah lateks cair dan remah karet, Nanopartikel silika (SiO2), TiO2 teknis, White oil (Softener), Zinc Oxide (Activator), Asam Stearat (Activator), Minarex Oil (Softener), Parafin Wax (Stabilizer), Sulfur (Curing Agent), SLES (Foaming Agent), CMC (Gelling Agent), Silicone Rubber, Minyak biji jarak, Minyak kayu putih dan amonia.

Pada dasarnya eksperimen ini dibagi menjadi beberapa tahap yaitu: Tahap perancangan dan pembuatan cetakan (mold), tahap sintesis, dan tahap karakterisasi material. Cetakan untuk membuat sampel sangat dibutuhkan dengan spesifikasi khusus, baik bahan, ukuran dan kinerjanya. Molding yang digunakan terbuat dari bahan besi steinless steel, dengan ukuran panjang $10 \mathrm{~cm}$, lebar $7 \mathrm{~cm}$, dan tinggi $3 \mathrm{~cm}$. Cetakan ini selain sebagai wadah mencetak juga berfungsi sebagai pemanas yang akan menyempurnakan pematangan curing.

Pada tahapan sintesis akan dibuat prekursor material komposit. Keseluruhan penelitian ini bergantung pada tahap pertama karena sifat dari material ditentukan oleh bahan penyusunnya. Dalam pembuatan prekursor ini akan dibuat variasi optimasi jenis bahan dasar karet yang digunakan (lateks cair, dan karet silikon). Sampel disintesis dengan mencampurkan beberapa bahan kimia, formula yang dipakai tergantung jenis bahan yang dipakai, urutan pemasukan bahan, waktu pengadukan dan jumlah bahan yang dipakai. Semua formula yang ditemukan akan diuji dan diulang terus sampai ditemukan formula yang paling tepat untuk menghasilkan nanokomposit yang paling mirip struktur mekaniknya dengan daging manusia. Bahan yang telah dicampur dengan bantuan mixer selama waktu tertentu (sesuai formula) kemudian dioven selama 2 jam pada suhu $150{ }^{\circ} \mathrm{C}$, kemudian dimasukkan dalam cetakan molding dan dihotpress selama 1 jam pada suhu $100{ }^{\circ} \mathrm{C}$. 
Pada tahapan karakterisasi material dipilih teknik karakterisasi material yang dibutuhkan beserta pengambilan data yang diperoleh dari karakterisasi material tersebut. Karakterisasi mekanik diukur menggunakan Universal Testing Machine, untuk mempelajari struktur permukaan secara atomik akan diuji dengan AFM (bisa diperoleh informasi mengenai: gambar 3D, kehalusan/kekasaran permukaan, dan kekuatan tarikmenarik), komposisi material diuji menggunakan FT-IR, dan untuk memperoleh gambaran permukaan serta komponen material secara kuantitatif akan diuji dengan SEMEDX. Sebagai kontrol juga diujikan daging sapi, lalu dibandingkan. Berdasarkan hasil karakterisasi semua sampel tersebut akan dilakukan analisa dan komparasi karakter material dengan referensi. Dari analisis tersebut lalu dirancang pemodelan untuk memperkirakan kekerasan kompon dan komposisi material yang tepat, lalu akan dilakukan penarikan kesimpulan dan saran terkait material yang telah dibuat.

\section{HASIL DAN DISKUSI}

Pada eksperimen ini dibuat campuran karet dengan agent yang tidak diberikan filler. Tujuannya adalah sebagai pembanding terhadap karet komposit, apakah bila diberikan fillerakan terdapat perbaikan karakteristik atau tidak. Maka dibuatlah karet tanpa filler yang berfungsi sebagai variable kontrol pada eksperimen ini.

Pada Gambar 1 terlihat hasil spektra FTIR untuk karet kontrol dan variasi optimasi jenis bahan dasar karet yang digunakan karet alam (lateks cair) dan karet sintetis (silikon). Sedangkan interpretasi ikatan yang ada dalam komposit ini terlihat pada Tabel 1.
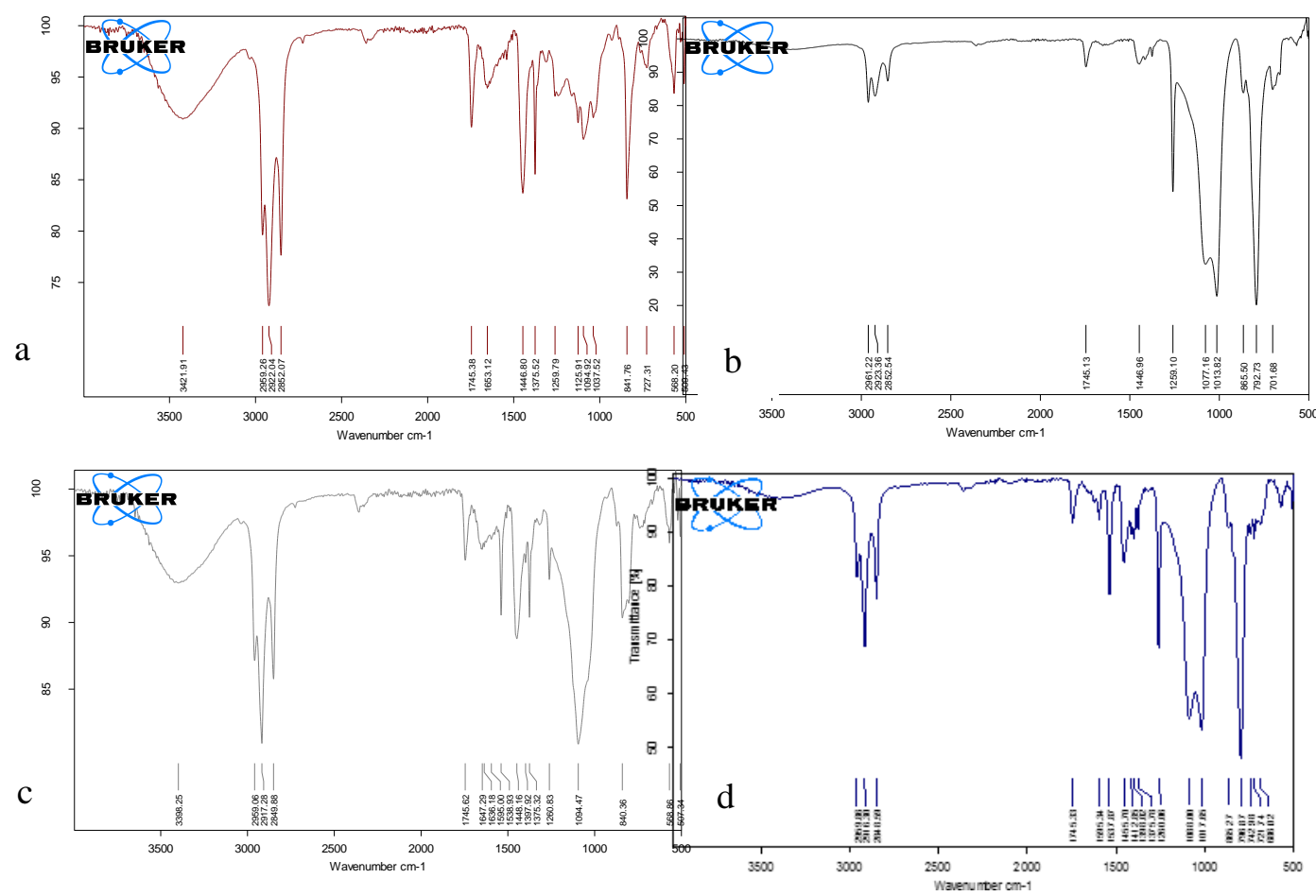

Gambar 1 Hasil Karakterisasi Transmitansi sampel kontrol 100\% lateks (a), sampel dengan Karet Komposit Lateks 50\% dan Silikon50\% (b), sampel dengan Karet

Komposit Lateks 75\% dan Silikon25\% (c) dan sampel dengan Karet Komposit Silikon $100 \%$ (d) 
Tabel 1 Interpretasi Karakterisasi FTIR Karet Komposit

\begin{tabular}{|l|l|}
\hline Ikatan & Wavenumber(cm-1) \\
\hline O-H Stretch & 3421 \\
\hline C-H Stretch & $2852-2959$ \\
\hline C-C Stretch & $1375-1446$ \\
\hline =C-H Bend & 841 \\
\hline
\end{tabular}

Dengan melihat pada hasil karakterisasi material ini, terlihat bahwa dengan komposisi lateks yang lebih banyak, material akan memiliki kekuatan yang lebih baik seiring dengan tingginya nilai modulus young yang mengindikasikan ketahanan suatu material saat ditarik. Sedangkan modulus Young dari material pada variasi ini dapat dilihat pada Gambar 2. Sampel 75NR 25S memiliki nilai modulus young yang cukup tinggi, ini mengindikasikan bahwa kombinasi karet alam dan karet silikon bisa menghasilkan ketahanan tarik komposit yang baik dengan komposisi yang tepat, sampel ini bahkan lebih baik daripada kombinasi yang sama besar antara karet alam dan silikon (50 NR 50S). Hasil ini adalah titik terang yang menggembirakan dimana karet alam akan lebih banyak terpakai sehingga memberi nilai tambah dalam upaya hilirisasi pemanfaatan karet alam.

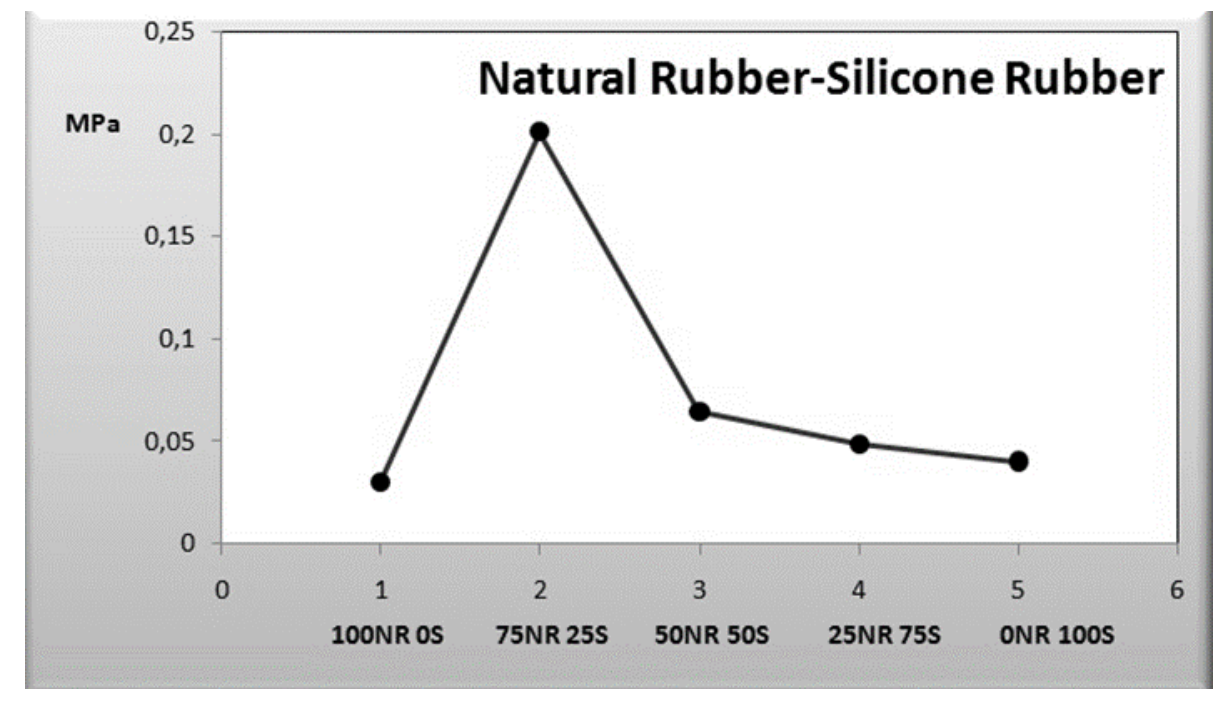

Gambar 2 Hasil Pengujian Modulus Young Sampel

Hasil pengujian Universal Testing Machine kemudian dibandingkan dengan literatur data karakteristik mekanik tubuh manusia yang seperti terlihat pada Tabel 2. 
Tabel 2 Karakteristik mekanik berbagai bagian tubuh manusia

\begin{tabular}{|c|c|c|c|c|}
\hline Bagian Tubuh & $\begin{array}{l}\text { Jenis } \\
\text { Kelamin }\end{array}$ & $\begin{array}{l}\text { Usia } \\
\text { (tahun) }\end{array}$ & $\begin{array}{l}\text { Modulus Young } \\
\text { (Mpa) }\end{array}$ & Referensi \\
\hline Otot Bicep & Pria & 65 & 49,02 & [4] \\
\hline Otot Bicep & Pria & 85 & 59,15 & [4] \\
\hline Otot Bicep* & Pria & 75 & 48,74 & [4] \\
\hline Kulit Punggung & & 30 & 200 & [5] \\
\hline Kulit Punggung & & 9 & 0,42 & [5] \\
\hline Tulang Rawan pada Lutut & Pria & 16 & 0,13 & [6] \\
\hline Tulang Rawan pada Lutut & Wanita & 65 & 1,91 & [6] \\
\hline Otot Bahu (Anterior) & & & 16,5 & [7] \\
\hline Otot Bahu (Middle) & & & 6 & [7] \\
\hline Otot Bahu (Posterior) & & & 4,1 & [7] \\
\hline Kerongkongan & & & 0,077 & [7] \\
\hline Usus & & & 0,0356 & [7] \\
\hline Usus* & & & 0,0359 & [7] \\
\hline Selaput Jantung & & & 2,51 & [7] \\
\hline Tendon (urat daging), Achilles tendon & & & 819 & [8] \\
\hline Tendon (urat daging), Patellar tendon & & & 643 & [9] \\
\hline Ligament (cruciate ligament) & & & 345 & [9] \\
\hline Semitendinosus tendon & & 26 & 362,2 & {$[10]$} \\
\hline Ligament (ligamentum flavum) & & muda & 98 & [11] \\
\hline Ligament (ligamentum flavum) & & Tua & 20 & [11] \\
\hline Ankle ligament (anterior talofibular ligament) & wanita & 27 & 86 & {$[12]$} \\
\hline $\begin{array}{l}\text { Tulang rawan (HWA of femoral condyle, } \\
\text { superficial zone) }\end{array}$ & & & 5 & [13] \\
\hline $\begin{array}{l}\text { Tulang rawan (HWA of femoral condyle, middle } \\
\text { zone) }\end{array}$ & & & 3,1 & {$[13]$} \\
\hline $\begin{array}{l}\text { Tulang rawan (LWA of femoral condyle, } \\
\text { superficial zone) }\end{array}$ & & & 10,1 & {$[13]$} \\
\hline $\begin{array}{l}\text { Tulang rawan (LWA of femoral condyle, middle } \\
\text { zone) }\end{array}$ & & & 5,4 & {$[13]$} \\
\hline
\end{tabular}

\section{KESIMPULAN}

Untuk variasi bahan dasar komposit, digunakan variasi komposisi bahan karet alam (lateks cair) dan karet sintetis (silikon) yaitu: Lateks 100\%, Lateks 75\% dan Silikon 25\%, Lateks 50\% dan Silikon 50\%, Lateks 25\% dan Silikon 75\%, dan Silikon 100\%. Dari 
semua variasi tersebut dapat dilihat bahwa material dengan komposisi lateks yang lebih banyak memiliki kekuatan yang lebih baik.

Dengan mengkomparasikan data modulus Young antara hasil eksperimen dengan daging/cadaver manusia maka dapat disimpulkan bahwa karet komposit lateks 50\% dan Silikon $50 \%$ pengujian $1(0,070 \mathrm{MPa})$ menyerupai kerongkongan $(0,77 \mathrm{MPa})$ serta pengujian $2(0,041 \mathrm{MPa})$ memiliki karakteristik mekanik yang menyerupai usus manusia $(0,0356 \mathrm{MPa})$. Karet komposit lateks $75 \%$ dan Silikon $25 \%$ pengujian $1(0,196 \mathrm{MPa})$ dan pengujian $2(0.136 \mathrm{MPa})$, memiliki karakteristik menyerupai tulang rawan pada lutut pria remaja $(0,13 \mathrm{MPa})$. Walaupun beberapa material sudah menyerupai organ bagian dalam manusia, namun nilai ini masih jauh dengan organ tubuh bagian luar dari manusia seperti otot yang dapat mencapai 49 Mpa.

\section{UCAPAN TERIMA KASIH}

Penulis mengucapkan terima kasih dukungan finansial dari BU BPKLN DIKTI sehingga penelitian dapat dilaksanakan dan kepada semua pihak yang membantu atas dukungannya dalam kegiatan penelitianyang telah dilakukan.

\section{DAFTAR PUSTAKA}

1. F. Ayers, dkk. (2008): Fabrication and characterization of silicone-based tissue phantoms with tunable optical properties in the visible and near infrared domain. Proc. of SPIE, 6870 (7), 1-9

2. Pogue, B.W. and M.S. Patterson, 2006: Review of tissue simulating phantoms for optical spectroscopy, imaging and dosimetry. J Biomed Opt, 11(4), 041102.

3. Kemenristek RI, (2014): Draft (4) Kebijakan Strategis Pembangunan Nasional Ilmu Pengetahuan dan Teknologi Tahun 2014-2019.

4. Egorov, Viacheslav I. et al. (2002): Mechanical Properties Of The Human Gastrointestinal Tract. Journal of Biomechanics, 35.10, 1417-1425.

5. Agache, P. G. et al. (1980): Mechanical Properties And Young's Modulus Of Human Skin In Vivo, Arch Dermatol Res, 269.3, 221-232.

6. Armstrong, C.G., dan V.C. Mow. (1982): Variations In The Intrinsic Mechanical Properties Of Human Articular Cartilage With Age, Degeneration, And Water Content. The Journal of Bone and Joint Surgery, 87-94.

7. Itoi, E et al. (1996): Tensile Properties of The Supraspinatus Tendon. Journal of Shoulder and Elbow Surgery, 5.2, S28.

8. Wren, T. A. L., S. A. Yerby, G. S. Beaupre and D. R. Carter. Mechanical properties of the human Achilles tendon. Clinical Biomechanics, 16 (2001), 245-251.

9. Butler, D. L., M. D. Kay and D. C. Stouffer. Comparison of material properties in fascicle-bone units from human patellar tendon and knee ligaments. Journal of Biomechanics, 19 (1986), 425-432.

10. Butler DL, Grood ES, Noyes FR, Zernicke RF, Brackett K (1984) Effects of structure and strain measurement technique on the material properties of young human tendons and fascia. J Biomech 17:579-596

11. Nachemson, A. L. and J. H. Evans. Some mechanical properties of the third human lumbar interlaminar ligament (ligamentum flavum). Journal of Biomechanics, 1 (1968), 211-220 
12. Pierre RKS, Rosen J, Whitesides TE, Szczukowski M, Fleming LL, Hutton WC (1983). The tensile strength of the anterior talofibular ligament. Foot Ankle 4:83-85

13. Akizuki, S., V. C. Mow, F. Muller, J. C. Pita, D. S. Howell et al. Tensile properties of human knee joint cartilage: I. Influence of ionic conditions, weight bearing, and fibrillation on the tensile modulus. Journal of Orthopaedic Research, 4 (1986), 379392. 